\title{
cDNA identification and gene expression of two types of acetylcholinesterases in a cultured cell line of Aedes albopictus, compared to mosquito whole body extracts
}

\author{
Hiroshi Mizuno, ${ }^{1, *}$ Takashi Tomita, ${ }^{2}$ Shinji KasaI, ${ }^{2}$ Osamu Komagata, ${ }^{2}$ Shigeo Imanishi $^{3}$ \\ and Yoshiaki Kono ${ }^{1}$ \\ ${ }^{1}$ Graduate School of Life and Environmental Sciences, University of Tsukuba; Tsukuba 305-8572, Japan \\ ${ }^{2}$ Department of Medical Entomology, National Institute of Infectious Disease; Shinjuku-ku, Tokyo 162-8640, Japan \\ ${ }^{3}$ Developmental Biology Department, National Institute of Agrobiological Sciences; Tsukuba 305-8634, Japan \\ (Received 2 December 2005; Accepted 7 April 2006)
}

\begin{abstract}
Two cDNA sequences containing open reading frames encoding two types of acetylcholinesterase (AChE) precursors, Ace-orthologous AChE (AO-AChE) and Ace-paralogous AChE (AP-AChE), with 635 residues and 702 residues, respectively, were determined in Aedes albopictus by PCR-based techniques. The partial and whole cDNAs for AO$\mathrm{AChE}$ and AP-AChE, respectively, were also sequenced from a cultured cell line of mosquito, NIAS-AeAl-2, derived from Ae. albopictus neonatal larvae. Comparing the sequences of the respective AChEs between cultured cells and mosquito whole body extracts, many nucleotide polymorphisms were found in both AChE cDNAs but only one amino acid substitution. The expression level of $\mathrm{AChE}$ genes in the cultured cells was low, $1 / 2$ and 1/7 that of the mosquito body for AO-AChE and AP-AChE, respectively. The expression ratio of AO-AChE/AP-AChE was 1/2 in the cultured cells. AP-AChE genes was more highly expressed than AO-AChE genes in both cultured cells and the mosquito body. In an enzyme assay, the activity of AChE per protein in the cultured cells was $1 / 8$ that of the mosquito body. The function of AChE in cultured cells is discussed based on the present and previous papers.
\end{abstract}

Key words: Ace-orthologous; Ace-paralogous; AChE; mosquito cell; real time PCR

\section{INTRODUCTION}

Acetylcholinesterase (AChE, EC 3.1.1.7) terminates neural excitement at the postsynaptic membrane by hydrolyzing the neurotransmitter, acetylcholine (ACh). In insects, AChE has mainly been studied in relation to insecticide resistance because the enzyme is the target of organophosphorus and carbamate insecticides and its insensitivity to insecticides is one of the main factors for resistance. The insect AChE gene was first sequenced in Drosophila melanogaster (Hall and Spierer, 1986) and several amino acid substitutions conferring insecticide insensitivity in AChE were first elucidated in this species as Ace (Mutero et al., 1994) followed by the Brachycera fly species, Musca domestica (Huang et al., 1997; Kozaki et al., 2001; Walsh et al., 2001), Lucilia cuprina (Chen et al.,
2001), and Bactrocera oleae (Vontas et al., 2002). However, no amino acid substitution in the Ace homologues (Ace orthologous AChE, AO-AChE) was found in other insects in which AChE insensitivity had been well characterized (Fournier and Mutero, 1994). Recently, a second type of AChE less homologous to Ace (Ace paralogous AChE, APAChE) was found in the green bug, Schizaphis graminum (Gao et al., 2002) and the mosquito, Anopheles gambiae (Weill et al., 2003). Amino acid substitutions at several different positions conferring insecticide insensitivity have been reported in AP-AChEs of Culex pipiens (Weill et al., 2003), An. gambiae (Weill et al., 2003), An. albimanus (Weill et al., 2004), C. tritaeniorhynchus (Nabeshima et al., 2004), M. persicae (Nabeshima et al., 2003), Aphis gossypii (Andrews et al., 2004; Toda et al., 2004) and Plutella xylostella (Baek et al.,

\footnotetext{
* To whom correspondence should be addressed at: E-mail: h-mizuno@kg8.so-net.ne.jp
} DOI: $10.1303 / \mathrm{aez} .2006 .445$ 
2005). Recent studies of several insect species have shown that the expression level of the AP-AChE gene was much higher than that of the AO-AChE gene, and suggest that AP-AChE plays a main role in terminating synaptic transmission. Therefore, a question as to the functions of $\mathrm{AChE}$ except for the primary function mentioned above, arises because of the existence of two types of the enzyme in insects. Some functions of $\mathrm{AChE}$ such as cell growth, cell-substrate adhesion and neurite growth have been suggested in vertebrates (Layer et al., 1993; Huby et al., 1999; Johnson and Moore, 1999; Ruben et al., 2004; Silman and Sussman, 2005). On the other hand, several insect cell lines having AChE activity have been reported (Ohbayashi et al., 1997). Cell lines of Ae. albopictus (NAISAeAl-2; Mitsuhashi, 1981) derived from neonatal larvae seem to be the best material for studying secondary functions because they have high AChE activity and the original insect species have two types of AChE. As the first step, we attempted to isolate cDNAs for two types of $\mathrm{AChE}, \mathrm{AO}-\mathrm{AChE}$ and AP-AChE, from both cultured cells and mosquito body, sequence their cDNAs and determine the expression of these $\mathrm{AChE}$ genes.

\section{MATERIALS AND METHODS}

Mosquito strain. The insecticide-susceptible strain of Ae. albopictus originating from Ikaken strain, Tokyo, Japan, was maintained at the National Institute of Infectious Diseases. Mosquitoes were reared under constant conditions at $25^{\circ} \mathrm{C}$ and a photoperiod 16L : 8D without insecticide exposure.

Cultured cells and culture medium. A cultured cell line, NIAS-AeAl-2, established from $A e$. albopictus neonate larvae by Mitsuhashi (1981) was used. The cells were cultured at $25^{\circ} \mathrm{C}$ in MM medium (Mitsuhashi and Maramorosch, 1964) containing 3\% fetal bovine serum (FBS). For enzyme assays, cells collected with a scraper (Sumilon) were centrifuged at $1,000 \times g$ for $10 \mathrm{~min}$ at $4^{\circ} \mathrm{C}$. The supernatant of culture media was removed and cells subjected to the AChE assay as follows.

Enzyme assays. Cultured cells and mosquito bodies were homogenized with a polytron in $1 \mathrm{ml}$ of $50 \mathrm{~mm}$ Tris- $\mathrm{HCl}(\mathrm{pH} 8.0)$ containing $0.1 \%$ Triton $\mathrm{X}-100$ and the homogenates were centrifuged at $1,000 \times g$ for $10 \mathrm{~min}$ at $4^{\circ} \mathrm{C}$. The supernatant was used as an enzyme source. The activity was measured according to the method of Ellman et al (1961) with minor modifications (Mamiya et al., 1997). Forty microliters of enzyme source were added to each well of a microtiter plate containing $140 \mu \mathrm{l}$ of $50 \mathrm{~mm}$ Tris- $\mathrm{HCl}$ buffer $(\mathrm{pH} 8.0)$ and $20 \mu \mathrm{l}$ of DTNB solution $(0.4 \mathrm{~mm}$ DTNB $+1.5 \mathrm{~mm}$ $\left.\mathrm{NaHCO}_{3}\right)$ to initiate the reaction $\left(25^{\circ} \mathrm{C}\right)$. Then $40 \mu \mathrm{l}$ of substrate and $1.0 \mathrm{~mm}$ acetylthiocholine (ATCh) were added to each well. Enzyme activity was measured photometrically at $412 \mathrm{~nm}$ and $25^{\circ} \mathrm{C}$ with a Microplate Reader Model 450 (Bio-Rad). Additionally, the amounts of protein in the cultured cells and mosquito whole bodies were determined with a BCA Protein Assay Kit (Pierce). Bovine serum albumin was used as the standard. The Michaelis constant $\left(K_{\mathrm{m}}\right)$ was calculated based on the results of the reaction with different concentrations of substrate (100 to $0.001 \mathrm{mM}$ ATCh). $K_{\mathrm{m}}$ values were estimated with a Lineweaver and Burk plot.

RNA extraction and cDNA synthesis. RNA was extracted from $115 \mathrm{mg}$ of adult mosquitoes and $8 \times 10^{6}$ cultured cells with Isogen (Nippon Gene) according to the manufacturer's protocol and directly used for reverse transcription. In both mosquito and cultured cells, first-strand full-length cDNA was synthesized with oligo (dT) primers $\left(\mathrm{QT}^{\prime}\right)$, SuperScript II (Invitrogen). The reaction volume was diluted to $40 \mu \mathrm{l}$ with distilled water. The first strand cDNA synthesized from $3 \mu \mathrm{g}$ total RNA was used in the PCR and $3^{\prime}-$ and $5^{\prime}$-RACE analyses.

Isolation of AChE cDNAs from mosquito body. cDNA synthesized from both mosquito and cultured cells was amplified with ExTaq DNA Polymerase (Takara). The reaction volume was $25 \mu \mathrm{l}$ including $0.5 \mu \mathrm{l}$ of template. For isolating AO-AChE cDNA from mosquito whole bodies, degenerate primers S18ACE and S20"ACE were used to amplify the first cDNA fragment and then a second PCR was performed with S24ACE and AS4ACE gene-specific and degenerate primers, respectively (see Table 1). Both PCR reactions were carried out at $94^{\circ} \mathrm{C}$ for $2 \mathrm{~min}$ as a preheat step, followed by 40 cycles at $94^{\circ} \mathrm{C}$ for $30 \mathrm{~s}, 50^{\circ} \mathrm{C}$ for $1 \mathrm{~min}, 68^{\circ} \mathrm{C}$ for $30 \mathrm{~s}$, and $72^{\circ} \mathrm{C}$ for $5 \mathrm{~min}$ as a final extension. The above product was nested with S24ACE and AS30ACE primers in a third PCR re- 
Table 1. Primers used in this study

\begin{tabular}{|c|c|c|c|}
\hline \multicolumn{2}{|r|}{ Forward primer } & \multicolumn{2}{|r|}{ Reverse primer } \\
\hline RT & & QT & $\mathrm{Q} 0-\mathrm{Q} 1^{\prime}-(\mathrm{dT})_{18}$ \\
\hline $\begin{array}{l}\text { AaA ChE1 } \\
\text { PCR }\end{array}$ & & & \\
\hline S18ACE & GGTGAAGAAATGTGGAAYCCNAATAC & $\mathrm{AS} 20 " \mathrm{ACE}$ & CATAAARCCDCCDCCRTAAATCCA \\
\hline S24ACE & TATCTGAATATCTGGGTGCCG & $\begin{array}{l}\text { AS4ACE } \\
\text { AS30ACE }\end{array}$ & $\begin{array}{l}\text { ACNCCCATCCAYTCNCCCCA } \\
\text { TGRTTYTGRTAICCRTCRTTICC }\end{array}$ \\
\hline 3'RACE & & & \\
\hline S38ACE & AACGTAATCGTGGCATCCAT & Q0 & CCAGTGAGCAGAGTGACG \\
\hline $\begin{array}{l}\text { S30ACE } \\
5^{\prime} \text { RACE }\end{array}$ & TCTGAGCCGGAGCGCGAAG & Q1' & GAGGACTCGAGCTCAAGC \\
\hline $\begin{array}{l}5 \text { 'Primer } \\
\text { Full length }\end{array}$ & GTCTACCAGGCATTCGCTTCAT & AS41ACE & TGTACACGTCCAGAGTCGATG \\
\hline $\begin{array}{l}\text { S55ACE } \\
\text { AaA ChE2 }\end{array}$ & TGATCAAATCGAGTGGTTTTTG & AS55ACE & ATAATATTAAGGTGGGGTGGGACAG \\
\hline PCR & & & \\
\hline $\begin{array}{l}\text { F7ACE } \\
3^{\prime} \text { RACE }\end{array}$ & ACIATGTGGAAYCCIAAYACICC & $\mathrm{R} 2 \mathrm{ACE}$ & TCTTCCGCATATCGCTGGGCAAAC \\
\hline F11ACE & AGCGTTCGCTAGCCAGTGGAC & Q0 & CCAGTGAGCAGAGTGACG \\
\hline F10ACE & CAGGCCGTTAGAGAGCTGAA & Q1' & GAGGACTCGAGCTCAAGC \\
\hline F20ACE & GGTGACGAGATCAACTATGTATTC & Q1' & GAGGACTCGAGCTCAAGC \\
\hline 5'RACE & & & \\
\hline & & R11ACE & TCTAGGGTAGCAGTACCGGAGT \\
\hline $\begin{array}{l}\text { AUAP } \\
\text { Full length }\end{array}$ & GGCCACGCGTCGACTAGTAC & R15ACE & TCGGATGTGACATGGACCTA \\
\hline F55ACE & ATTGCGGACGAGTAAACCTC & R55ACE & GTAGTATTGATGTTATTTTGCAACCA \\
\hline
\end{tabular}

action. The $3^{\prime}$ end of the cDNA was amplified with gene-specific primers (S38ACE and Q0 having the anchor sequence of $\mathrm{QT}^{\prime}$ and nested with S30ACE and $\mathrm{Q} 1^{\prime}$ ) under conditions of $95^{\circ} \mathrm{C}$ for $2 \mathrm{~min}$, followed by 40 cycles at $95^{\circ} \mathrm{C}$ for $30 \mathrm{~s}, 53^{\circ} \mathrm{C}$ for $30 \mathrm{~s}$, $72^{\circ} \mathrm{C}$ for $2 \mathrm{~min}$, and $72^{\circ} \mathrm{C}$ for $5 \mathrm{~min}$. To isolate the $5^{\prime}$ end, a Capfishing ${ }^{\mathrm{TM}}$ Full-length cDNA Premix Kit (Seegene) was used according to the manufacturer's protocol. The first cDNA fragment was amplified with 5' primer and AS41ACE primer at conditions of $95^{\circ} \mathrm{C}$ for $2 \mathrm{~min}$, followed by 30 cycle at $95^{\circ} \mathrm{C}$ for $30 \mathrm{~s}, 58^{\circ} \mathrm{C}$ for $30 \mathrm{~s}, 72^{\circ} \mathrm{C}$ for $2 \mathrm{~min}$, and $72^{\circ} \mathrm{C}$ for $5 \mathrm{~min}$.

For isolating AP-AChE cDNA from mosquito whole bodies, the thermal cycler program was $95^{\circ} \mathrm{C}$ for $2 \mathrm{~min}$ as a preheat step, followed by 35 cycles at $95^{\circ} \mathrm{C}$ for $30 \mathrm{~s}, 50^{\circ} \mathrm{C}$ for $30 \mathrm{~s}, 72^{\circ} \mathrm{C}$ for 1 $\mathrm{min}$, and $72^{\circ} \mathrm{C}$ for $5 \mathrm{~min}$ as a final extension. Degenerate primer and gene-specific primers (F7ACE and R2ACE) were used to amplify the first cDNA fragment. Gene-specific primer R2ACE was designed based on the fragment reported by Weill et al. (2002, GenBank No. AJ438598). The 3' end of the cDNA was amplified with AP-AChE-specific primers (F11ACE and Q0 for first PCR, then F10ACE and Q1' for second PCR and nested with F20ACE and Q1' for third PCR). For isolating the 5' end, 5' RACE system, version 2.0 (Invitrogen) was used according to the manufacturer's protocol. The first cDNA fragment was amplified with R11ACE, and then this product was amplified with an abridged universal amplification primer (AUAP) and R15ACE.

Each of $0.5 \mu \mathrm{g}$ total RNA derived from five individual adult mosquitoes was reverse-transcribed and amplified by PCR for gene-specific primers (AO-AChE: S55ACE and AS55ACE; AP-AChE: F55ACE and R55ACE) and their sequences were determined.

Isolation of AChEs cDNA from cultured cells. For isolating full-length AP-AChE cDNA from cultured cells, PCR was performed with the genespecific primers F55ACE and R55ACE at $95^{\circ} \mathrm{C}$ for 2 min as a preheat step, followed by 40 cycles at $95^{\circ} \mathrm{C}$ for $30 \mathrm{~s}, 55^{\circ} \mathrm{C}$ for $30 \mathrm{~s}, 72^{\circ} \mathrm{C}$ for $2.5 \mathrm{~min}$, and $72^{\circ} \mathrm{C}$ for $5 \mathrm{~min}$ as a final extension. To isolate $\mathrm{AO}$ - 
AChE cDNA from cultured cells, degenerate primers (S18ACE and AS4ACE) were used in a first PCR reaction and nested with S18ACE and AS30ACE at $94^{\circ} \mathrm{C}$ for $2 \mathrm{~min}$ as a preheat step, followed by 40 cycles at $94^{\circ} \mathrm{C}$ for $30 \mathrm{~s}, 50^{\circ} \mathrm{C}$ for $1 \mathrm{~min}, 72^{\circ} \mathrm{C}$ for $1 \mathrm{~min}$, and $72^{\circ} \mathrm{C}$ for $5 \mathrm{~min}$ as a final extension. Although we successfully isolated full-length AO-AChE cDNA with S55ACE and AS55ACE from mosquito whole bodies, we were unable to isolate full-length AO-AChE cDNA with their primers and other primers (data not shown) from cultured cells.

DNA sequencing. Amplified sequences were determined by direct sequencing using a BigDye Terminator v1.1 Cycle Sequencing Kit (Applied Biosystems, Tokyo) and a Genetic Analyser 3100 System (Applied Biosystems).

Quantitative real time PCR. Total RNAs of cultured cells and mosquito whole bodies extracted with Isogen (Nippon Gene) were purified with a RNase-Free DNase Set and RNeasy Mini Kit (Qiagen) according to the manufacturer's protocols. First-strand cDNAs were synthesized from respective $4-5 \mu \mathrm{g}$ of RNAs in a $20 \mu \mathrm{l}$ volume using ReverTra Ace (Toyobo) as described in the manufacturer's protocol. To acquire the accurate production of standard curves, 98 and $132 \mathrm{bp}$ of PCR products from respective $\mathrm{AO}-\mathrm{AChE}$ and $\mathrm{AP}-\mathrm{AChE}$ were serially diluted to $0.08 \mathrm{amol} / \mu 1,0.40 \mathrm{amol} / \mu 1,2.00$ $\mathrm{amol} / \mu \mathrm{l}$ and $10.00 \mathrm{amol} / \mu \mathrm{l}$, and $85 \mathrm{bp} \mathrm{cDNA}$ from ribosomal RPS3 was diluted to $2.00 \mathrm{amol} / \mu \mathrm{l}$, $10.00 \mathrm{amol} / \mu 1,50.00 \mathrm{amol} / \mu 1$ and $250.00 \mathrm{amol} / \mu 1$. The PCR product of ribosomal RPS3 was used to determinate the relative transcription level of AChE. The PCR products and synthesized firststrand cDNAs with the primers specified in Table 1 were used as template for quantitative real-time PCR (qrtPCR). The reactions were performed in $12.5 \mu \mathrm{l}$ of iQ SYBR Green Supermix (Bio-Rad), 1 $\mu 1$ of template, $0.5 \mu 1$ of each $10 \mu \mathrm{M}$ primer (Table 1 bottom) and made up to $25 \mu 1$ with distilled water. PCR was conducted with 1 cycle of $95^{\circ} \mathrm{C}$ for $3 \mathrm{~min}, 50$ cycles of $95^{\circ} \mathrm{C}$ for $15 \mathrm{~s}, 54^{\circ} \mathrm{C}$ for $30 \mathrm{~s}$, and $72^{\circ} \mathrm{C}$ for $30 \mathrm{~s}$; 1 cycle of $95^{\circ} \mathrm{C}$ for $1 \mathrm{~min} ; 1$ cycle of $50^{\circ} \mathrm{C}$ for $1 \mathrm{~min}$; and finally 90 cycles of $50-95^{\circ} \mathrm{C} / 10 \mathrm{~s}$, increasing the setpoint temperature by $0.5^{\circ} \mathrm{C}$ to generate melting curves. The qrtPCR reaction was repeated three times for each sample. The results were analyzed and their initial copy numbers determined by optical system software
Table 2. $K_{\mathrm{m}}$ value and specific activity of cultured cells and whole body extracts of mosquito larvae

\begin{tabular}{|c|c|c|}
\hline Source & $\begin{array}{c}K_{\mathrm{m}} \\
\left(\times 10^{-5} \mathrm{M}\right)\end{array}$ & $\begin{array}{c}\text { AChE activity } \\
(\mathrm{nmol} / \mathrm{h} / \mathrm{mg} \\
\text { protein) }\end{array}$ \\
\hline Cultured cell (NIAS-AeAl-2) & 2.27 & $1,159.9$ \\
\hline First instar larvae & 1.57 & $8,161.3$ \\
\hline
\end{tabular}

iCycler iQ version 3.0 (Bio-Rad).

\section{RESULTS}

\section{Enzyme assay}

The specific activity and $K_{\mathrm{m}}$ values of AChE in cultured cells and mosquito whole bodies were determined and are shown in Table 2. AChE activity of the cultured cell was 1/7 of the mosquito body. $K_{\mathrm{m}}$ values of cultured cells and mosquito bodies were similar in value and the ratio of first-instar larvae to cultured cells was 0.69 . Both values were close to that of Culex tritaeniorhynchus AO-CxT $(0.0338 \mathrm{~mm})$ and AP-CxTS $(0.0363 \mathrm{~mm})$ (Oh et al., 2006). The ratio of first larva to AO-CxT and APCxTS was 0.46 and 0.43 , respectively.

\section{AO-AChE and AP-AChE CDNA sequences of mosquito body}

Nucleotide sequences of cDNAs for AOAaAChE (2438bp) and AP-AaAChE (2182 bp) with open reading frames (ORF) of 635 and 702 amino acid residues, respectively were determined from five Ikaken strain specimens. The cleavage of the signal peptide in $\mathrm{AO}-\mathrm{AaAChE}$ and $\mathrm{AP}$ $\mathrm{AaAChE}$ was predicted to be between $\mathrm{Gly}_{26} / \mathrm{Ile}_{27}$ and $\mathrm{Cys}_{36} / \mathrm{Arg}_{37}$, respectively, from the first methionine. These protein precursor sequences are shown in Fig. 1, with sequences from two other mosquito species An. gambiae and C. tritaeniorhynchus, D. melanogaster and Torpedo californica. Common features of $\mathrm{AChE}$ are conserved in both AO-AaAChE and AP-AaAChE: the catalytic triad (AO-AaAChE: $\mathrm{Ser}_{256}, \mathrm{Glu}_{385}, \mathrm{His}_{499}$, APAaAChE: Ser $_{327}, \mathrm{Glu}_{453}, \mathrm{His}_{567}$ ), three pairs of Cys residues (AO-AaAChE: $\mathrm{Cys}_{92-119}, \mathrm{Cys}_{310-325}$, $\mathrm{Cys}_{461-583}$, AP-AaAChE: Cys ${ }_{195-222}, \mathrm{Cys}_{381-394}$, $\mathrm{Cys}_{529-650)}$ putatively forming intra-subunit disulfide bonds and 9 and 11 aromatic residues lining the active site gorge of $T$. californica in AO- 


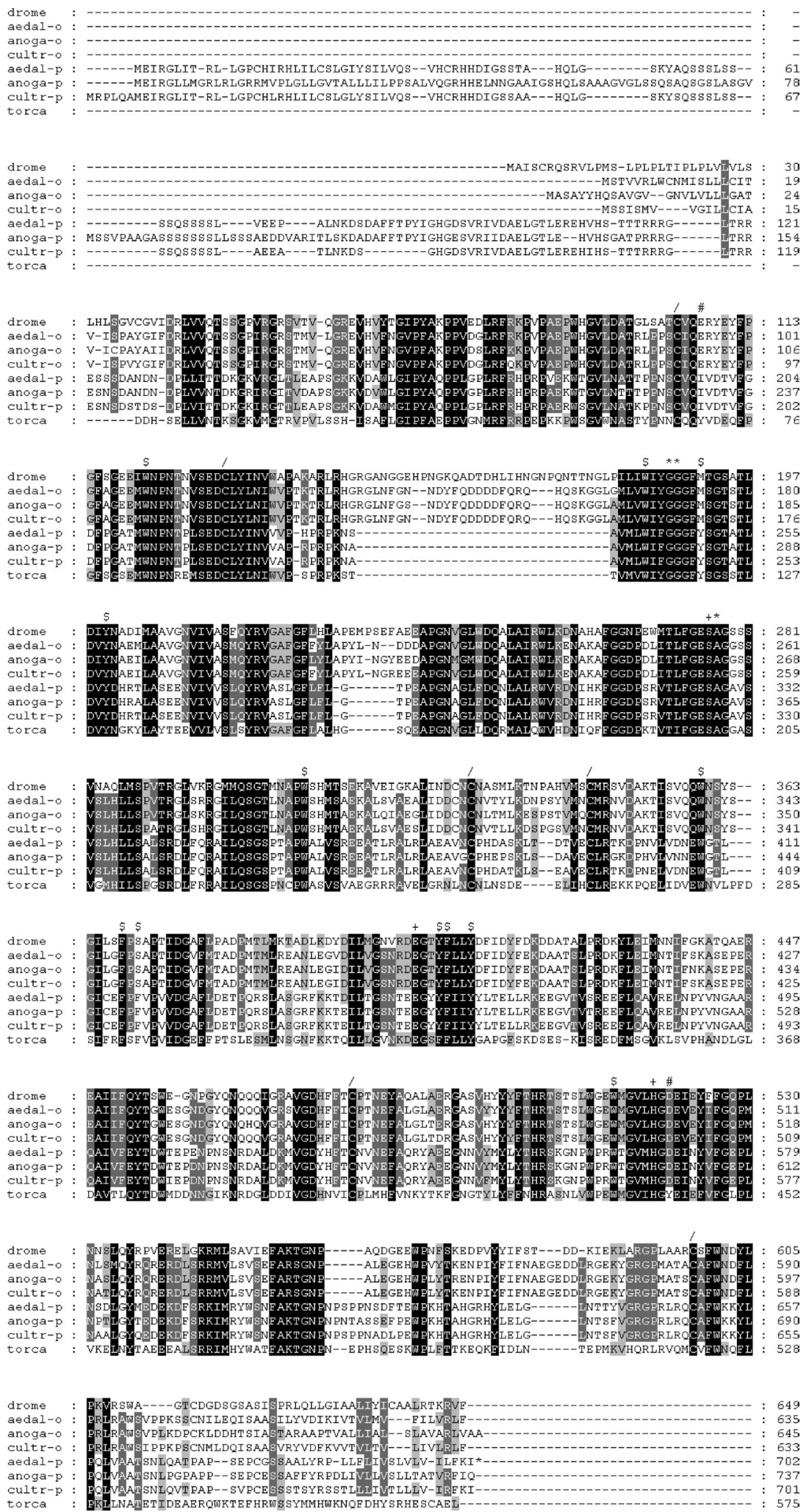

Fig. 1. Alignment of AChE1(-o) and AChE2(-p) proteins of Ae. albopictus (aedal), An. gambiae (anoga), C. tritaeniorhynchus (cultr), D. melanogaster (drome), and T. californica (torca). Residues involved in the catalytic triad of T. californica. AChE are shown with plus signs. Aromatic residues of the active site gorge in T. californica. AChE that are conserved and not involved in insect AChEs are shown with dollar and sharp symbols, respectively. Slashes show intra-subunit-forming disulfide bonds in $T$. californica AChE. 
Table 3. Codons and deduced amino acids of the variable positions in the AO-AChE gene of Ae. albopictus

\begin{tabular}{|c|c|c|c|c|c|c|c|c|c|c|c|c|}
\hline \multirow{2}{*}{ Source } & \multicolumn{12}{|c|}{ Polymorphic nucleotide positions (codons) } \\
\hline & 454 & 525 & 528 & 567 & 576 & 579 & 651 & 691 & 774 & 891 & 1071 & 1137 \\
\hline Mosquite body & TTC & AGY & GGT & GCA & GGA & AAT & GCA & TTG & GGT & GCT & CTG & GTT \\
\hline Cultured cell & ATC & AGC & GGC & GCG & GGG & AAC & GCG & CTG & GGC & GCC & CTA & GTA \\
\hline $\begin{array}{l}\text { Codon } \\
\text { (position) }\end{array}$ & $\begin{array}{c}\mathrm{Phe} \rightarrow \text { Ile } \\
(152)\end{array}$ & $\begin{array}{c}\text { Ser } \\
(175)\end{array}$ & $\begin{array}{l}\text { Gly } \\
(176)\end{array}$ & $\begin{array}{l}\text { Ala } \\
(189)\end{array}$ & $\begin{array}{c}\text { Gly } \\
(192)\end{array}$ & $\begin{array}{c}\text { Asn } \\
(193)\end{array}$ & $\begin{array}{c}\text { Ala } \\
(217)\end{array}$ & $\begin{array}{l}\text { Leu } \\
(231)\end{array}$ & $\begin{array}{l}\text { Gly } \\
(258)\end{array}$ & $\begin{array}{l}\text { Ala } \\
(297)\end{array}$ & $\begin{array}{l}\text { Leu } \\
(357)\end{array}$ & $\begin{array}{c}\text { Val } \\
(379)\end{array}$ \\
\hline
\end{tabular}

Table 4. Codons and deduced amino acids of the variable positions in the AP-AChE gene of Ae. albopictus

\begin{tabular}{|c|c|c|c|c|c|c|c|c|c|c|c|c|c|c|c|}
\hline \multirow{2}{*}{ Source } & \multicolumn{15}{|c|}{ Polymorphic nucleotide positions (codons) } \\
\hline & 160 & 405 & 483 & 588 & 780 & 789 & 891 & 960 & 975 & 1053 & 1068 & 1530 & 1767 & 1854 & 2093 \\
\hline $\begin{array}{c}\text { Mosquite } \\
\text { body }\end{array}$ & GCA & ATC & ATC & GTT & CCC CAT & CTC GAG & TTG & CGG & GGT & CTC & $\mathrm{CCC}$ & AAY & GAR & TTY & AAY \\
\hline Cultured cell & TCA & ATM & ATY & GTC & CCA CAY & CTY GAR & TTR & CGR & GGC & CTS & $\mathrm{CCY}$ & AAT & GAG & TTT & $\mathrm{AAC}$ \\
\hline $\begin{array}{l}\text { Codon } \\
\text { (position) }\end{array}$ & $\begin{array}{l}\mathrm{Ala} \rightarrow \text { Ser } \\
\quad(54)\end{array}$ & $\begin{array}{l}\text { Ile } \\
(135)\end{array}$ & $\begin{array}{l}\text { Ile } \\
(161)\end{array}$ & $\begin{array}{c}\text { Val } \\
(196)\end{array}$ & $\begin{array}{cc}\text { Pro } & \text { His } \\
(234) & (260)\end{array}$ & $\begin{array}{cc}\text { Leu } & \text { Glu } \\
(263) & (267)\end{array}$ & $\begin{array}{l}\text { Leu } \\
\text { (297) }\end{array}$ & $\begin{array}{c}\text { Arg } \\
(320)\end{array}$ & $\begin{array}{l}\text { Gly } \\
(325)\end{array}$ & $\begin{array}{l}\text { Leu } \\
(351)\end{array}$ & $\begin{array}{l}\text { Pro } \\
(356)\end{array}$ & $\begin{array}{l}\text { Asn } \\
(510)\end{array}$ & $\begin{array}{l}\text { Glu } \\
(589)\end{array}$ & $\begin{array}{l}\text { Phe } \\
(618)\end{array}$ & $\begin{array}{l}\text { Asn } \\
(731)\end{array}$ \\
\hline
\end{tabular}

AaAChE and AP-AaAChE residues. AO-AaAChE and AP-AaAChE precursors show high identities to the respective types of $\mathrm{AChE}, 91 \%$ and $84 \%$ with An. gambiae and $93 \%$ and $93 \%$ with C. tritaeniorhynchus, respectively. On the other hand, the identities of AO-AChE to AP-AChE with Ae. albopictus, An. gambiae and C. tritaeniorhynchus are $42 \%, 39 \%$ and $39 \%$, respectively. cDNA sequence polymorphisms were observed at five and four positions of AO-AChE and AP-AChE, respectively.

\section{Comparison of AChE cDNA sequences between mosquito body and cultured cells}

Both AO-AChE and AP-AChE cDNAs were isolated from cultured cells. For AO-AChE, a partial region $818 \mathrm{bp}$ isolated in cultured cells was compared with the mosquito body from $\mathrm{Asp}_{118}$ to $\mathrm{Phe}_{389}$ : 12 base pair substitutions and only one amino acid substitution $\mathrm{Ile}_{152}$ to $\mathrm{Phe}_{152}$ were found (Table 3). The first methionine ATG and stop codon compared in AP-AChE, cDNA sequence polymorphisms were observed at 17 positions (Table 4). Only one amino acid substitution was presented at $\operatorname{Ser}_{54}$ to $\mathrm{Ala}_{54}$.

Expression level of $\mathrm{AO}-\mathrm{AChE}$ and $\mathrm{AP}-\mathrm{AChE}$ genes in mosquito body and cultured cells

Expression levels of AP-AChE and AO-AChE

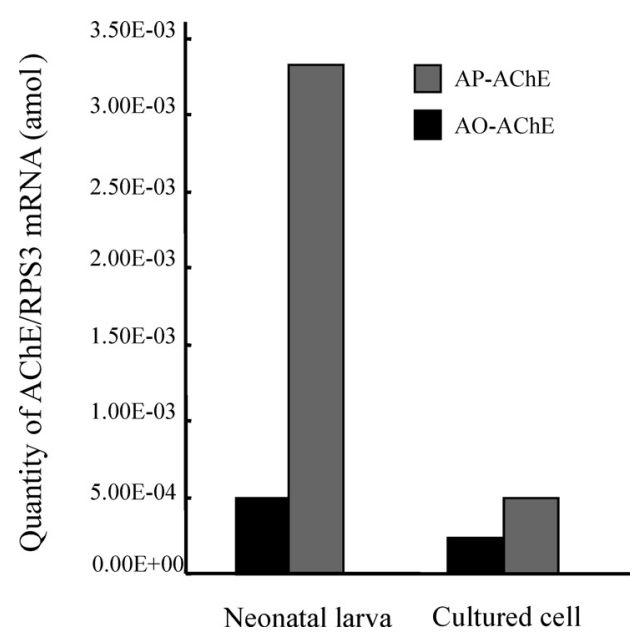

Fig. 2. The expression level per RPS3 of AO-AChE and AP-AChE genes in cultured cells and mosquito larvae.

genes in cultured cells and mosquito whole bodies were determined and compared by qrtPCR. The results are shown in Fig. 2. The expression level of $\mathrm{AO}-\mathrm{AChE}$ gene was low compared to AP-AChE gene in both the mosquito bodies and cultured cells; $1 / 7$ in the first-instar larvae and $1 / 2$ in the cultured cells. The ratios for mosquito bodies to cultured cells were two and seven in $\mathrm{AO}-\mathrm{AChE}$ and AP-AChE, respectively. The expression level of the reference gene RPS3 in the cultured cells and mosquito bodies were standardized. 


\section{DISCUSSION}

Two types of acetylcholinesterases (AO-AChE and $\mathrm{AP}-\mathrm{AChE}$ ) were isolated from the tiger mosquito, Ae. albopictus, and complete amino acid sequences of both structural proteins were determined. The structural proteins of the two types had all amino acids for the enzyme function and showed very high homology to the respective proteins in other mosquitoes. We also showed by PCR cloning that cultured cells originating from neonatal larvae of Ae. albopictus expressed two types of AChE mRNAs. A complete amino acid sequence of AP-AChE and partial sequence of AO-AChE were determined. When the sequences of the cultured cells were compared with those of the respective AChE type in the mosquito, only one non-synonymous substitution was found among many nucleotide polymorphisms in both AChE cDNAs. $\mathrm{The} \mathrm{Ala}_{54}$ to $\mathrm{Ser}_{54}$ substitution in AP-AChE is located at a cleaved region during formation of the mature protein (Haas et al., 1988) and the $\mathrm{Ile}_{152}$ to $\mathrm{Phe}_{152}$ substitution in $\mathrm{AO}-\mathrm{AChE}$ is located at the $\mathrm{N}$-terminus. Both are thought not to affect the properties of enzyme activity. These results seem to support the conclusion that both AChEs keep their functions in the cultured cells. As for AO$\mathrm{AChE}$, however, the cDNA product of the cultured cells could not be amplified from the first-strand cDNA after even more than 80 PCR cycles with gene-specific primers for isolating the full-length cDNA (data not shown). 5' RACE or 3' RACE were also tried with gene-specific primers of the mosquito AChE, but a specific band was not obtained. It has been reported that there are long UTR promoting erroneous fusions occur during PCR in marginal regions of the AChE gene in $P$. xylostella (Ni et al., 2003; Baek et al., 2005).

In cultured cells, only 1/7 AChE activity was detected compared to the first-instar larvae of the mosquito. The activity measured appears to be a mixture of both types of AChEs which is apparently expressed in the mosquito body and cultured cells. The activities of two AChE could not be differentiated by enzyme assay.

To elucidate the exact expression of both types of AChE genes in the mosquito body and cultured cells, qrtPCR was adopted. QrtPCR showed that the expression level of AO-AChE was lower than AP-AChE gene in the mosquito body and cultured cells. The total AChE gene expression in cultured cells was $1 / 5$ that in the larvae. The gene expression level and enzyme activity of AChE in cultured cells was comparable, taking the fluctuation of the protein quantity in insect tissues and cultured cells into account.

In addition to NIAS-AeAl-2, several insect cell lines, such as NIH-SaPe-4 originating from embryonic tissues of Sarcophaga peregrina, NIAS-MB32 from the ovary of Mamestra brassicae (Ohbayashi et al., 1997) and S3 from $D$. melanogaster (Berger and Wyss, 1980) have been reported to have high AChE activity. However, the existence of AChE activity in insect cell lines does not depend on their origins: for example; Kc, SL-3, SES-BoMo-15A, TUAT-BME-11 and 15 cell lines derived from embryonic tissues; NIAS-MB-25 from $M$. brassicae ovary; and SL-3, the mother cell line of S3, showed no AChE activity (Ohbayashi et al., 1997). These examples seem to indicate that the expression of $\mathrm{AChE}$ is not essential for cultured cells. On the other hand, AChE is known to promote cell proliferation in vertebrate and nematode cell lines (Huby et al., 1999; Ruben et al., 2004) and to play a role in cell adhesion (Johnson and Moore, 1999). In the NIH-SaPe-4 cell line, inhibition of AChE activity by eserine did not affect cell growth (Ohbayashi et al., 1997), eserine which inhibited $80-90 \%$ of AChE activity in NIAS-AeAl-2 cultured cells brought no effect and the recovery of the activity occurred in $5 \mathrm{~d}$ (Mizuno, unpublished data). If AChE has functions besides ACh hydrolysis (non-cholinergic function) in these cultured insect cells, AChE protein without catalytic activity must have a role. The 'peripheral' anionic site has been shown to be associated with the non-cholinergic functions of AChE (Johnson and Moore, 1999; Silman and Sussman, 2005). To elucidate the functions of AChE, gene-silencing experiments with RNA interference, for example, seem to be the best procedure for cultured cells.

\section{ACKNOWLEDGEMENTS}

We thank Dr. DeMar Taylor, Graduate School of Life and Environmental Sciences, University of Tsukuba for critically reading the manuscript. This work was supported by a Grantin-Aid from the Ministry of Education, Culture, Sports, Science and Technology, Japan (No.14206005). 


\section{REFERENCES}

Andrews, M. C., A. Callaghan, L. M. Field, M. S. Williamson and G. D. Moores (2004) Identification of mutations conferring insecticide-insensitive $\mathrm{AChE}$ in the cottonmelon aphid, Aphis gossypii Glover. Insect Mol. Biol. 13: 555-561.

Baek, J. H., J. I. Kim, D. W. Lee, B. K. Chung, T. Miyata and S. H. Lee (2005) Identification and characterization of acel-type acetylcholinesterase likely associated with organophosphate resistance in Plutella xylostella. Pestic. Biochem. Physiol. 81: 164-175.

Berger, E. and C. Wyss (1980) Acetylcholinesterase induction by beta-ecdysone in Drosophila cell lines and their hybrids. Somatic Cell Genet. 6: 631-640.

Chen, Z., R. Newcomb, E. Forbes, J. McKenzie and P. Batterham (2001) The acetylcholinesterase gene and organophosphorus resistance in the Australian sheep blowfly, Lucilia cuprina. Insect Biochem. Mol. Biol. 31: 805-816.

Ellman, G. L., K. D. Courtny, U. Andres and K. M. Featherstore (1961) A new and rapid colorimertric determination of acetylcholinesterase activity. Biochem. Pharmacol. 7: 88-95.

Fournier, D. and A. Mutero (1994) Modification of acetylcholinesterase as a mechanism of resistance to insecticides. Comp. Biochem. Physiol. C 108: 19-31.

Gao, J. R., S. Kambhampati and K. Y. Zhu (2002) Molecular cloning and characterization of a greenbug (Schizaphis graminum) cDNA encoding acetylcholinesterase possibly evolved from a duplicate gene lineage. Insect Biochem. Mol. Biol. 32: 765-775.

Haas, R., T. L. Marshall and T. L. Rosenberry (1988) Drosophila acetylcholinesterase: demonstration of a glycoinositol phospholipid anchor and an endogenous proteolytic cleavage. Biochemistry 27: 6453-6457.

Hall, L. M. and P. Spierer (1986) The Ace locus of Drosophila melanogaster: structural gene for acetylcholinesterase with an unusual $5^{\prime}$ leader. EMBO J. 5: 2949-2954.

Huang, Y., C. Qiao, M. S. Williamson and A. L. Devonshire (1997) Characterization of the acetylcholinesterase gene from insecticide-resistant houseflies (Musca domestica). Chin. J. Biotechnol. 13: 177-183.

Huby, F., S. Mallet and H. Hoste (1999) Role of acetylcholinesterase (AChE) secreted by parasitic nematodes on the growth of the cell line from epithelial origin HT29-D4. Parasitology 118: 489-498.

Johnson, G. and S. W. Moore (1999) The adhesion function on acetylcholinesterase is located at the peripheral anionic site. Biochem. Biophys. Res. Commun. 258: 758-762.

Kozaki, T., T. Shono, T. Tomita and Y. Kono (2001) Fenitroxon insensitive acetylcholinesterases of the housefly, Musca domestica associated with point mutations. Insect Biochem. Mol. Biol. 31: 991-997.

Layer, P. G., T. Weikert and R. Alber (1993) Cholinesterases regulate neurite growth of chick nerve cells in vitro by means of a non-enzymatic mechanism. Cell Tissue Res.
273: 219-226.

Mamiya, A., Y. Ishikawa and Y. Kono (1997) Acetylcholinesterase in insecticide resistant Culex tritaeniorhynchus: characteristics accompanying insensitivity to inhibitors. Appl. Entomol. Zool. 32: 37-44.

Mitsuhashi, J. (1981) A new continuous cel line from larvae of the mosquito Aedes albopictus. Biomed. Res. 2: 599-606.

Mitsuhashi, J. and K. Maramorosch (1964) Leafhopper tissue culture: embryonic, nymphal, and imaginal tissue from aseptic insects. Contrib. Boyce Thompson Inst. 22: 435-460.

Mutero, A., M. Pralavorio, J. M. Bride and D. Fournier (1994) Resistance-associated point mutations in insecticide-insensitive acetylcholinesterase. Proc. Natl. Acad. Sci. USA 91: 5922-5926.

Nabeshima, T., T. Kozaki, T. Tomita and Y. Kono (2003) An amino acid substitution on the second acetylcholinesterase in the pirimicarb-resistant strains of the peach potato aphid, Myzus persicae. Biochem. Biophys. Res. Commun. 307: 15-22.

Nabeshima, T., A. Mori, T. Kozaki, Y. Iwata, O. Hidoh, S. Harada, S. Kasai, S. W. Severson, Y. Kono and T. Tomita (2004) An amino acid substitution attributable to insecticide-insensitivity of acetylcholinesterase in a Japanese encephalitis vector mosquito, Culex tritaeniorhynchus. Biochem. Biophys. Res. Commun. 313: 794-801.

Ni, X. Y., T. Tomita, S. Kasai and Y. Kono (2003) cDNA and deduced protein sequence of acetylcholinesterase from the diamondback moth, Plutella xylostella (Lepidoptera: Plutellidae). Appl. Entomol. Zool. 38: 49-56.

Oh, S. H., T. Kozaki, H. Mizuno, T. Tomita and Y. Kono (2006) Expression of Ace-paralogous acetylcholinesterase of Culex tritaeniorhynchus with an amino acid substitution conferring insecticide insensitivity in baculovirus-insect cell system. Pestic. Biochem. Physiol. 85: 46-51.

Ohbayashi, H., J. Mitsuhashi and K. Sato (1997) Comparison of acetylcholinesterases from adult heads of the flesh fly, Sarcophaga peregrina (Diptera: Sarcophagidae) and from its cell line, in response to several inhibitors. Appl. Entmol. Zool. 32: 521-523.

Ruben, S., H. Bettye, B. Erin and S. Timothy (2004) Primary culture of Lobster (Homarus americanus) olfactory sensory neurons. Chem. Senses 29: 179-187.

Silman, I. and J. L. Sussman (2005) Acetylcholinesterase: 'classical' and 'non-classical' functions and pharmacology. Curr. Opin. Pharmacol. 5: 293-302.

Toda, S., S. Komazaki, T. Tomita and Y. Kono (2004) Two amino acid substitutions in acetylcholinesterase associated with pirimicarb and organophosphorous insecticide resistance in the cotton aphid, Aphis gossypii Glover (Homoptera: Aphididae). Insect Mol. Biol. 13: 549-553.

Vontas, J. G., M. J. Hejazi, N. J. Hawkes, N. Cosmidis, M. Loukas, R. W. Janes and J. Hemingway (2002) Resistance-associated point mutations of organophosphate insensitive acetylcholinesterase, in the olive fruit fly Bactrocera oleae. Insect Mol. Biol. 11: 329-336.

Walsh, S. B., T. A. Dolden, G. D. Moores, M. Kristensen, T. 
Lewis, A. L. Devonshire and M. S. Williamson (2001) Identification and characterization of mutations in housefly (Musca domestica) acetylcholinesterase involved in insecticide resistance. Biochem. J. 359: 175-181.

Weill, M., P. Fort, A. Berthomieu, M. P. Dubois, N. Pasteur and M. Raymond (2002) A novel acetylcholinesterase gene in mosquitoes codes for the insecticide target and is non-homologous to the ace gene in Drosophila. Proc. R. Soc. Lond. B 269: 2007-2016.

Weill, M., G. Lutfalla, K. Mogensen, F. Chandre, A.
Berthomieu, C. Berticat, N. Pasteur, A. Philips, P. Fort and M. Raymond (2003) Comparative genomics: insecticide resistance in mosquito vectors. Nature 423: 136-137.

Weill, M., C. Malcolm, F. Chandre, K. Mogensen, A. Berthomieu, M. Marquine and M. Raymond (2004) The unique mutation in ace-1 giving high insecticide resistance is easily detectable in mosquito vectors. Insect Mol. Biol. 13: 1-7. 